\title{
NEW SPIDERS FROM CANADA AND THE ADJOINING STATES.
}

BY J. H. EMERTON, BOSTON, MASS.

In examining a large number of spiders from Canada and the northern United States, the following species appear to be undescribed. Six of them are from Metiakatla and other parts of the coast of British Columbia, collected by J. H. Keen and now in the collection of Nathan Banks, by whom several had been recognized as new and partly prepared for publication. Three are from Departure Bay on Vancouver Island, collected by T. B. Kurata, of Toronto. Two are from the mountains near Banff, collected by N. B. Sanson. Four are from Mt. Whiteface in the Adirondack Mts. of Northern New York, collected by the writer and C. R. Crosby, of Cornell University. The two Philodromus are from Ontario; one of them very common all over the eastern part of Canada.

\section{Lophocarenum sculptum, n. sp.}

A little over $2 \mathrm{~mm}$. long. Legs and palpi dull yellow. Cephalothorax and abdomen dark brown. Abdomen with a hard spot covering the whole back of the male and nearly the whole of the female as in L. excavatum, and in several Ceratinella. The abdomen is covered with depressed spots around the hairs. The
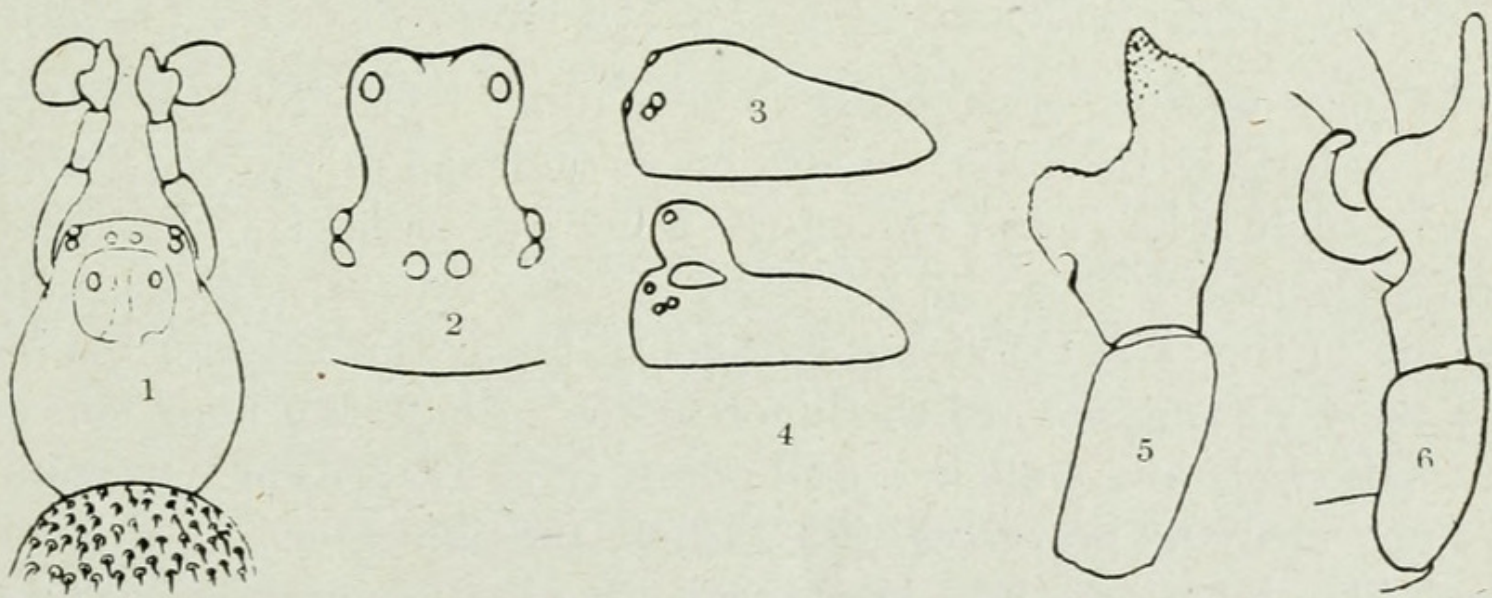

Fig 12.-Lophocarenum sculptum.-1, back of cephalothorax, part of abdomen and palpi of male; 2 , front of head of male; 3 , profile of cephalothorax of female; 4 , profile of cephalothorax of male; 5 , male palpus seen from above; 6 , male palpus, outer side.

head of the male has a small, abrupt hump, carrying the upper middle eyes near the top; (Fig. 12,2 and 4) it is slightly notched in the middle and constricted at the sides and in front, and under the August, 1917 
constricted part on each side is a deep groove. The female has a slight elevation of the head just behind the eyes. (Fig. 12,3.) The male palpi are moderately long with the patella twice as long as it is wide, and the tibia widened at the end, with a pointed process on the inner side extending over the tarsus. (Fig. 12, 5 and 6.)

Metlakatla, B.C., from J. H. Keen in Nathan Banks' collection.

\section{Aræoncus patellatus, n. sp.}

$2 \mathrm{~mm}$. long, pale without markings. The head is slightly elevated, more in the male than in the female. The upper eyes are more than their diameter apart, and farther apart in the male than in the female, almost touching the lateral eyes. (Fig. 13, 3.) The front middle eyes are small and near together, and as far from the upper eyes as these are from each other. The lateral eyes are in pairs touching each other, and surrounded by a common, dark border. The space between the eyes is covered by short, stift hairs directed upward. (Fig. 13,3.) The male palpi resemble slightly

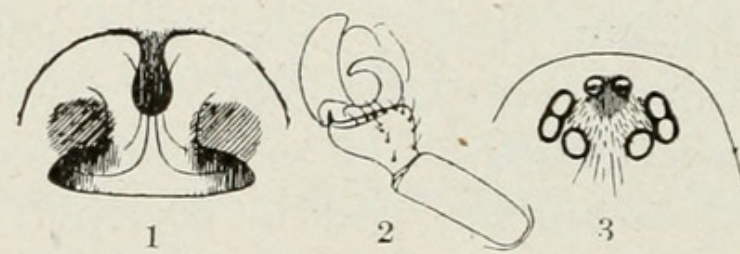

Fig. 13.-Arconcus patellatus.-1, epigynum; 2, male palpus, outer side; 3 , head of male from above.

those of Arconcus bispinosus. The patella is, as in bispinosus, twice as long as the tibia. The tibia is widened at the end, twice as wide as it is long, and has on the inner side a short, sharp tooth directed forward. (Fig. 13, 2). There are two rows of stiff hairs on the top of the tibia extending parallel as far as the anterior border and there turning toward the inner tooth. The tarsal hook curves in a half circle and ends in a dull point. (Fig. 13, 2.) The epigynum has two median processes, (Fig. 13, 1) the inner one T-shaped, much like the middle lobe in many Lycosidæ, the outer half as long and paddle-shaped.

Metlakatla, B.C., J. H. Keen.

\section{Gongylidium curvitarsis, n. sp.}

$4 \mathrm{~mm}$. long. Cephalothorax and legs pale yellow-brown. Abdomen gray with small, light spots of irregullar shape and 
arrangement, the middle ones sometimes in pairs. Size and general appearance like Pedanostethus riparius. The head is only slightly narrowed in front, but more in the male than in the female. The upper eyes are all of the same size and equal distances apart, the lower front pair half as large as the others and close together, but not touching. (Fig. 14,5.) In the male the metatarsi of the front
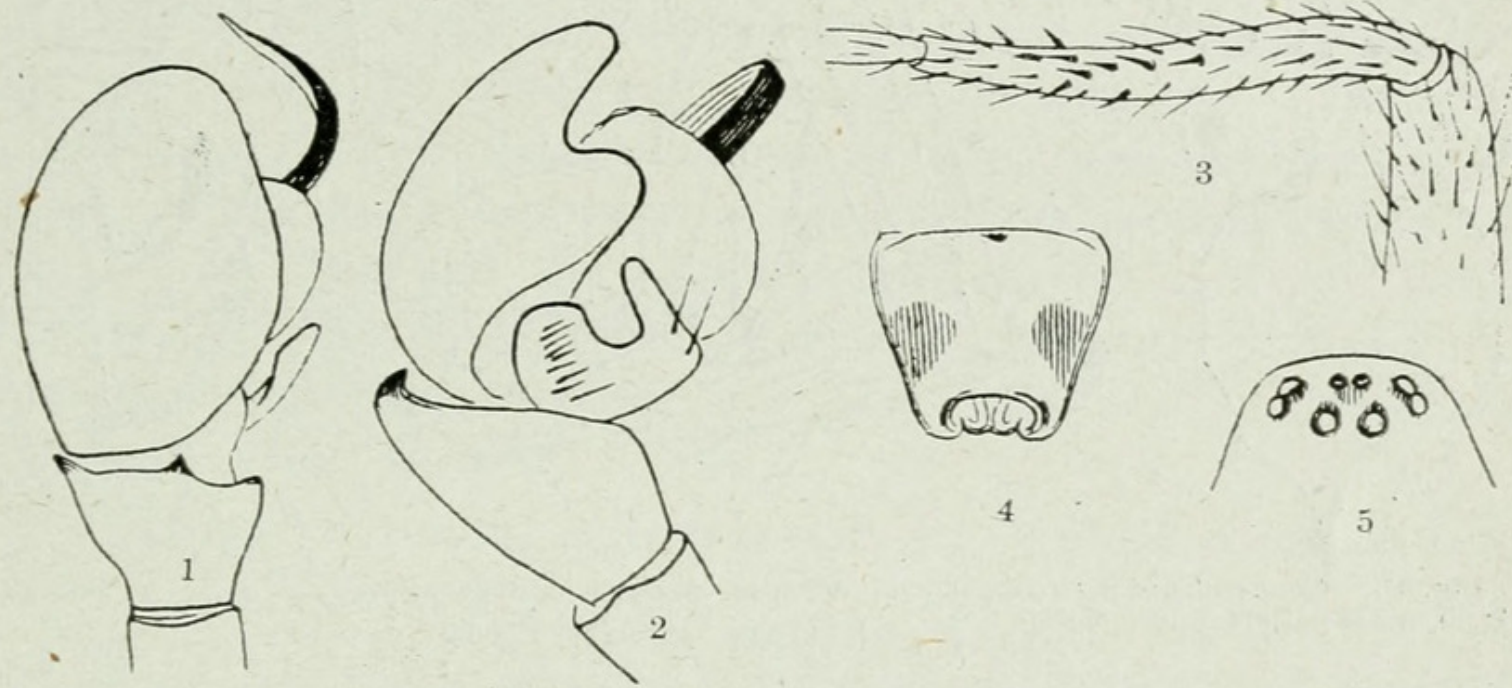

4

5

Fig. 14.-Gongylidium curvilarsis.-1, male palpus, from above; 2, male palpus, outer side; 3 , metatarsus of first leg of male; 4 , epigynum; 5 , eyes.

legs are slightly curved, and some of the hairs near the middle of the joint are thicker than the others. (Fig. 14,3.) The male palpi resemble closely those of $G$. (Tmeticus) brunneus Em. of the White Mountains, but the tibia has a sharper and more recurved point, (Fig. 14, 2) the tarsal hook though nearly of the same shape has the point less widened and the palpal organ has a long, stiff tube curved in a half circle and extending beyond the end of the tarsus. (Fig. 14, 1 and 2.) The epigynum is like that of brunneus but longer, projecting farther from the surface of the abdomen (Fig. 14, 4).

Mt. Whiteface, Adirondacks, N.Y., in moss in spruce forest at 4,000 ft.. May 24, 1916.

\section{Gongylidium macrochelis, n. sp.}

$3 \mathrm{~mm}$. long. Abdomen gray. Cephalothorax, legs and palpi dull orange. Resembles in size and colour Tmeticus armatus Bks., with which it was found. The head is low and wide, and the mandibles large and thick with a large tooth on the front and inner side as in probatus and tridentatus. The front of the mandibles has scattered elevations at the base of the hairs and on the 
outer sides are fine, parallel, horizontal lines. There are three or four small teeth on the inner side of the claw groove. (Fig. 15, 1 and 2.) The maxillæ are wide and have several scattered elevations with one larger one near the front. The male palpi are
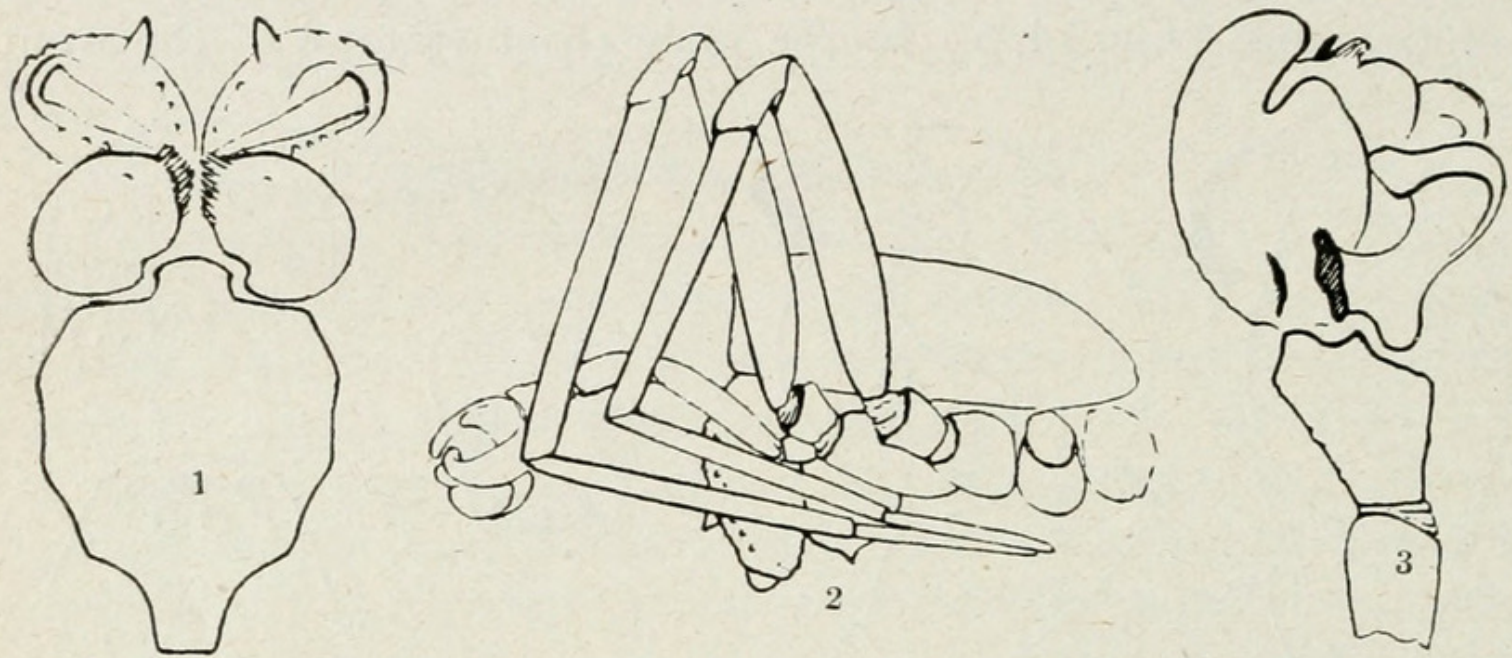

Fig. 15.-Gongylidium macrochelis.-1, sternum, maxillæ and mandibles of male; 2, side of male; 3 , male palpus, outer side.

long, with both patella and tibia longer than wide. The tibia is widened toward the end but has no large processes. (Fig. 15, 3.) The tarsus is short and round and has a deep notch on the outer side. The tarsal hook is of a complicated shape, shown in (Fig. 15, $3)$. The base is thickened and near it is a round tooth turned toward the tibia. The end of the hook curves outward and reaches back to the edge of the tarsus.

Sulphur Mountain, Banff, N.B. Sanson. In April on snow in company with Tmeticus armatus.

\section{Gongylidium unidentatum, n. sp.}

$1.5 \mathrm{~mm}$. long. Cephalothorax and abdomen gray and legs pale. Eyes as in Tmeticus bidentatus. Mandibles without any
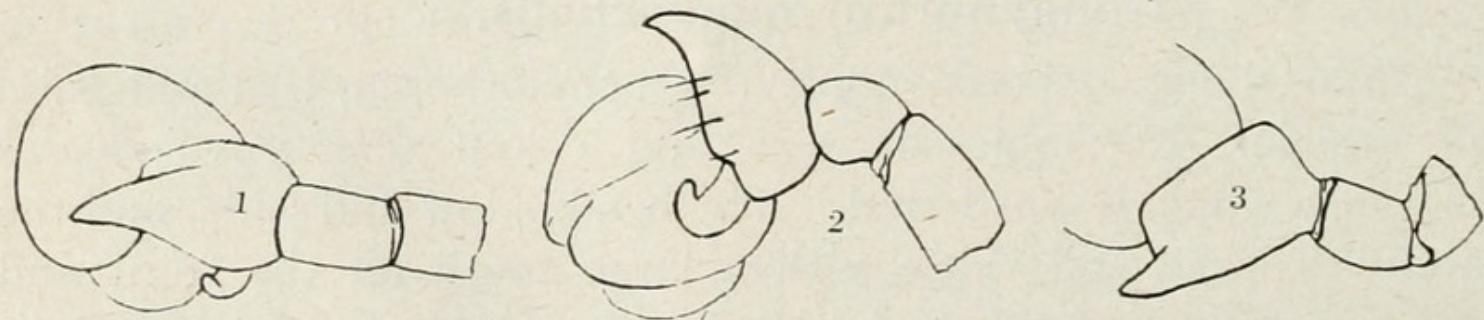

Fig. 16.-Gongylidium unidentatum.-1, male palpus, above; 2 , male palpus, outer side; 3 , male palpus, inner side. 
large tooth in front. Tarsus of male palpus extending over the tarsus half its length and pointed, with the point slightly turned down. (Fig. 16, 1, 2 and 3.) Tarsal hook simple.

Mt. Whiteface, Adirondacks, N.Y., C. R. Crosby. One specimen.

Microneta clavata, n. sp.

$2 \mathrm{~mm}$. long, pale yellowish. Both sexes of the same size. The male palpi are small and coloured like the legs. The tibia is thickened toward the end, where it is as wide as long. The tarsal hook is simple in form, the basal half straight, following the edge of the tibia and the terminal half curved in a half circle (Fig. 17, 3.) The epigynum is large, with a smooth, rounded end extending backward, turned a little way from the surface of the abdomen. (Fig. 17, 4.)

Wilmington Notch, Adirondacks, N.Y. C. R. Crosby.

\section{Microneta pallida, n. sp.}

A little over $2 \mathrm{~mm}$. long and pale, without any markings. The abdomen is slightly thickened in front and pointed behind. The front of the head extends a little forward beyond the mandibles. The mandibles are thickened at the base and have a few
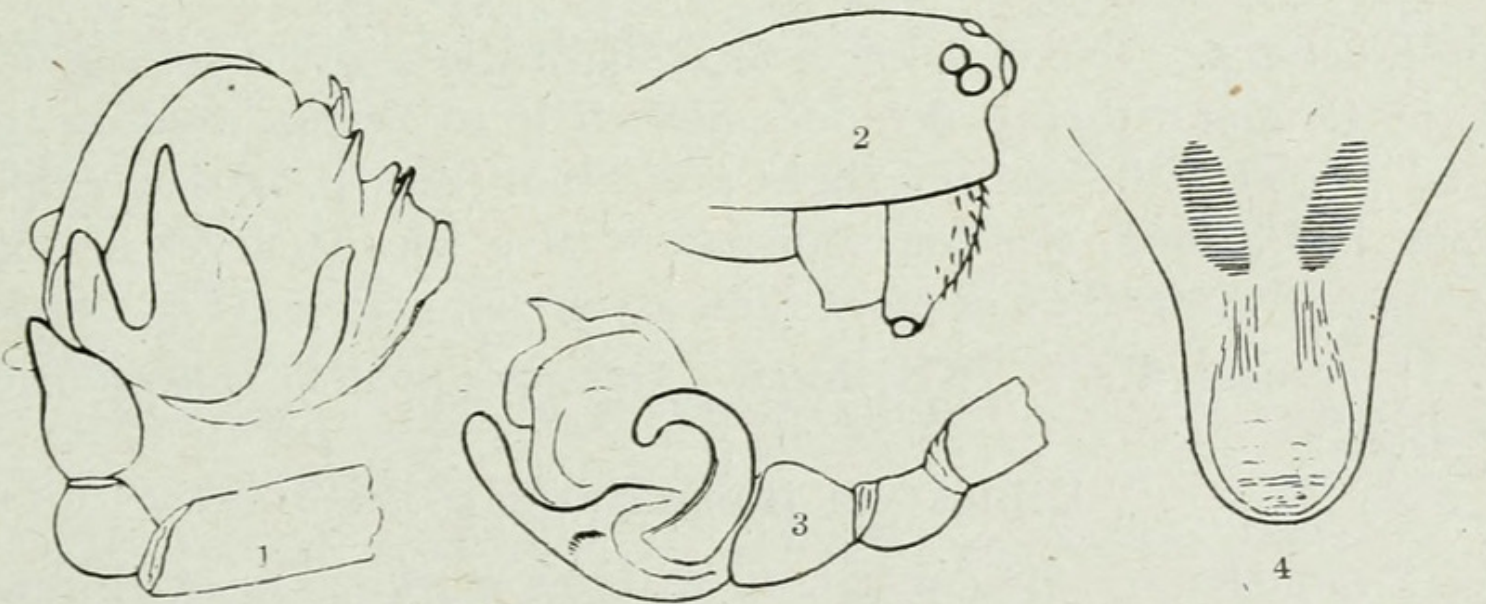

Fig. 17.-Microneta pallida. -1 , outer side of male palpus; 2 , profile of head and mandibles, Microneta clavita. -3 , male palpus; 4 epigynum.

stiff hairs on the front as in angulata and formica. (Fig. 17,2.) The male palpi have the tibia thickened in the middle and the end extended on the upper side over the tarsus. (Fig. 17,1.) The tarsal hook is wide and flat as in angulata. The tarsus has on the upper 
side two processes, neither very large; one near the base and the other in the middle.

Departure Bay, Vancouver Is., 1913, T. B. Kurata.

\section{Microneta orcina, n. sp.}

$2 \mathrm{~mm}$. long. Legs pale. Cephalothorax pale yellow brown. Abdomen pale gray with lighter spots in pairs as in several Diplostyla and Bathyphantes. (Fig. 18, 1.) The cephalothorax is nearly as wide as long, with the front of the head not much over half as wide. The male palpi have the tibia enlarged at the end without

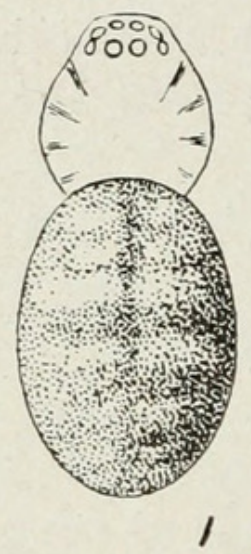

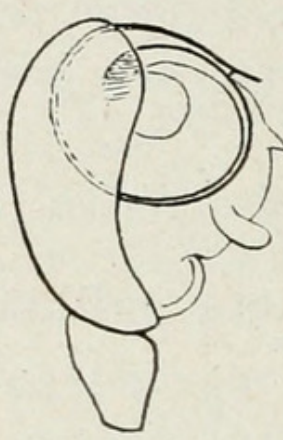

2

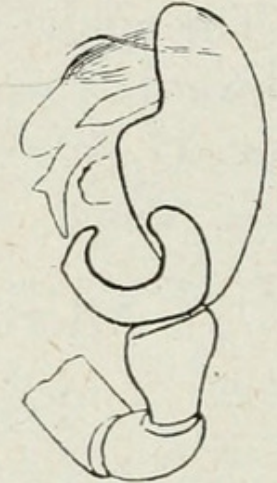

3

Fig. 18.-Microneta orcina.-1, dorsal markings of male; 2, male palpus; 3, male palpus, outer side.

any processes. The tarsal hook is straight where it crosses the end of the tibia and then curves in a half circle to a point, and on the outer side near the end is a slight projection (Fig 18,3.) The palpal organ has a long, slender, transparent tube which curves around the end of the palpus in more than a complete circle. (Fig. 18, 2.)

Inverness, B.C. J. H. Keen. One specimen in collection of N. Banks.

Diplostyla inornata, n. sp.

$2 \mathrm{~mm}$. long. Abdomen gray without markings or with only a trace of markings. Cephalothorax gray but lighter than the abdomen. Legs pale without markings. Palpi of male resembling those of nigrina, except that the tarsal hook is only slightly widened at the tip (Fig. 19,5) and the basal process is slightly curved inward over the coil of the tube. (Fig. 19,6.)

Mt. Whiteface, Adirondacks, N. Y., August, 1916. 


\section{Diplostyla keenii, n. sp.}

$3 \mathrm{~mm}$. long. Cephalothorax pale with light gray radiating markings. Legs long and pale with faint gray rings at the end and middle of each joint. Abdomen pale with distinct gray markings, two pairs of large spots more or less connected on the front

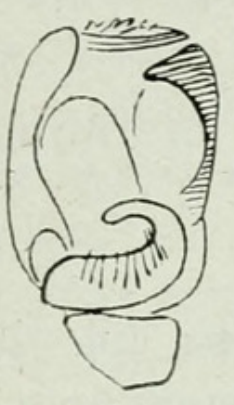

1
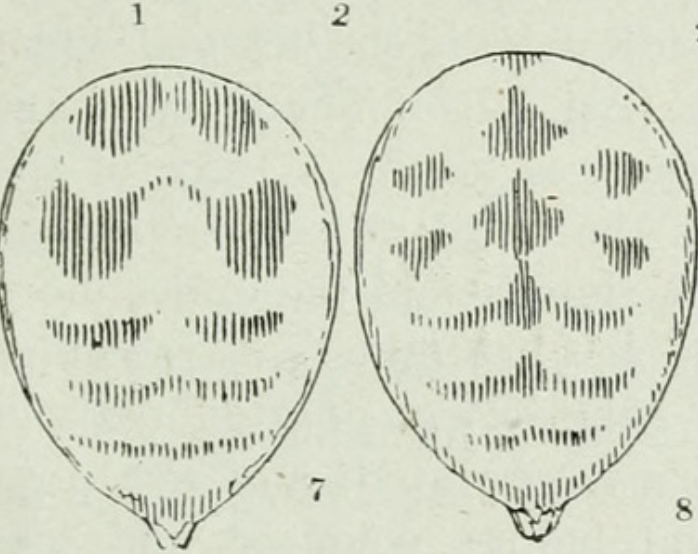

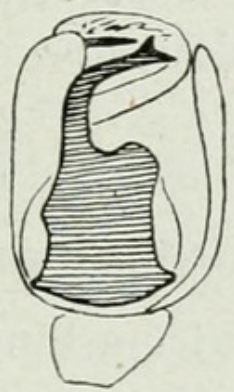

4

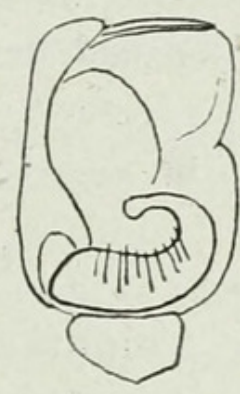

5

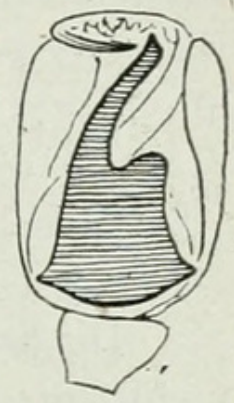

6

Fig. 19.-Diplostyla. -1 and 2 , male palpus of $D$. keenii; 3 and 4 , male palpus of $D$. brevipes; 4 and 5 , male palpus of $D$. inornata; 7 , dorsal markings of $D$. keenii; 8 , dorsal markings of $D$. brevipes.

half and three transverse on the hinder half, the front one divided in two. (Fig. 19, 7.) The male palpus has the tarsal hook blunt pointed. (Fig. 19,1.) The basal process is wide in the middle, with the inner corner much elongated. The slender portion turns off at a right angle. (Fig. 19,2.) The epigynum is of the usual shape but very short, as in alboventris.

Metlakatla, J. H. Keen, in collection of Nathan Banks.

\section{Diplostyla brevipes, n. sp.}

$3 \mathrm{~mm}$. long. Cephalothorax and legs pale, dull yellow without any markings. Abdomen whitish with gray markings; on the front half, two spots in the middle line, each partly connected with two lateral spots; behind these three transverse marks, the front one partly divided in three (Fig. 19, 8.) The legs are unusually 
short, the first femur but little longer than the cephalothorax. The male palpus has the tarsal hook pointed at the tip, and it is more pointed at the base than in the other species. (Fig. 19, 3.) The basal process of the palpal organ has the slender portion bent in the middle at nearly a right angle, and its point has a tooth turned outward as in alboventris, (Fig. 19,4.) The epigynum has the two processes straight and of middle length.

Metlakatla, B.C. J. H. Keen, in the collection of Nathan Banks.

\section{Pardosa metlakatla, n. sp.}

In size, colour and markings resembling $P$. glacialis, but differing from it in the epigynum and male palpi. The epigynum is narrow like that of atra, but the middle lobe is shorter and wider and widened at the end as in sternalis. (Fig. 20,3.) There is no large depressed area as in glacialis, and there is hardly a trace of the anterior pits. The palpal organ has the basal process somewhat - crescent-shaped, the lower point being shorter and the upper more pointed than in glacialis. (Fig. 20,4.) The small process on the outer side which supports the end of the tube is less pointed than in glacialis. The tarsus is longer and more pointed, and the tibia less thickened than in glacialis, and lighter coloured and less thickly covered with hair.

Metlakatla, B.C. J. H. Keen. Mountains north of Vancouver. W. Taylor.
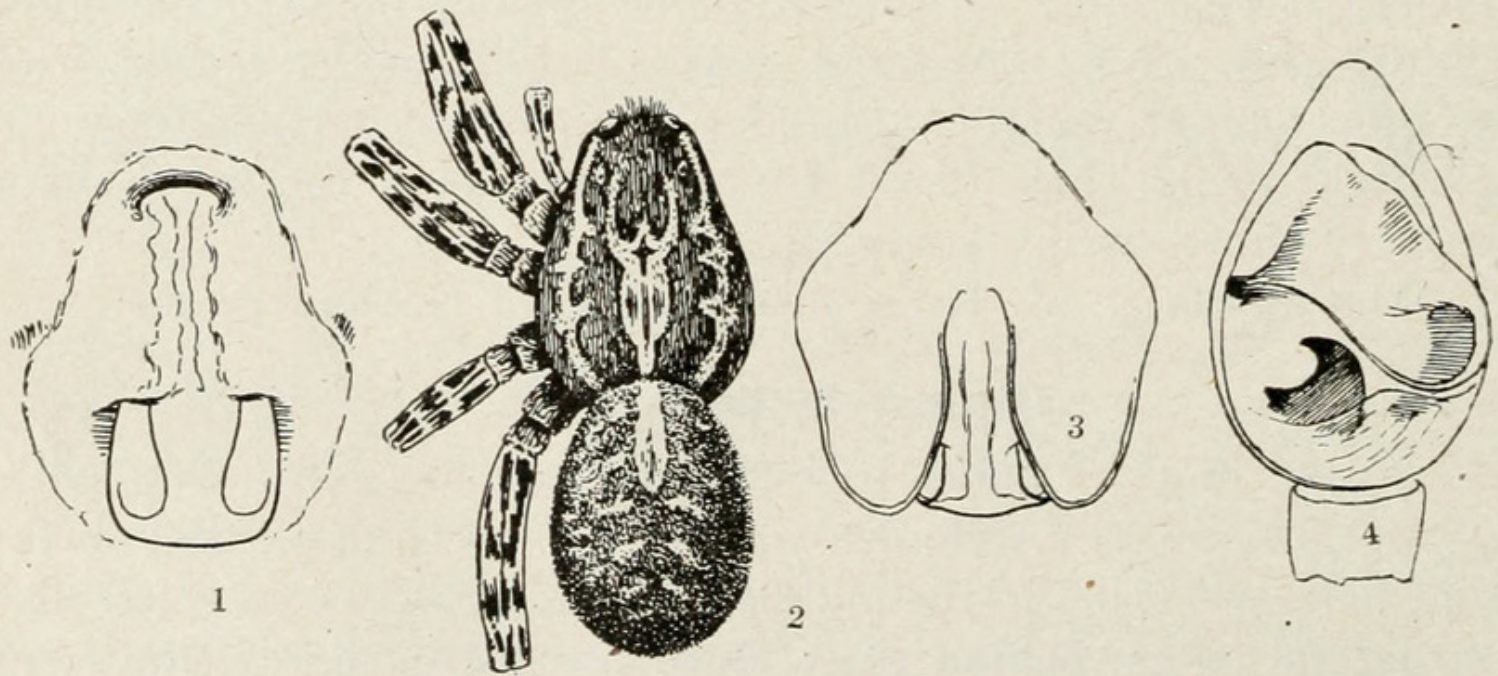

Fig, 20.-Pardosa vancouveri.-1, epigynum; 2, dorsal markings. Pardosa metlakatla.-3, epigynum; 4, male palpus. 


\section{Pardosa vancouveri, n. sp.}

$7 \mathrm{~mm}$. long. Gray with the colour much broken into spots of irregular shape. The cephalothorax has three light stripes, the middle one two-thirds as long as the cephalothorax, widened at the front end and divided in three. (Fig. 20,2.) The side stripes extend the whole length of the cephalothorax and are of irregular width. The legs are darkest at the base, and have broken and irregular spots on all the joints. The abdomen has the usual long middle spot at the front end, behind which are small, irregular, light spots in pairs. On the under side the colours are somewhat lighter on the coxæ and femora, and the abdomen has three indefinite dark stripes on a light ground. The epigynum is long and partly divided into two parts. The anterior end has a wide, distinct pit, from which a soft and narrow ridge extends backward as far as the transverse division. (Fig. 20,1.) The posterior half has a wide middle lobe in which is a ridge approaching the form of a T. (Fig. 20,1.) The male is yet unknown.

Departure Bay and Vancouver, in gardens and fields. T. B. Kurata.

\section{Pnecilochroa columbiana, n. sp.}

Cephalothorax $2.5 \mathrm{~mm}$. long. Abdomen variable in size according to contents. Cephalothorax orange brown with black hairs. Legs orange yellow except the femora, which are dark like the cephalothorax, the first and second femora sometimes darker than the others. The abdomen is black with a white, transverse stripe at the front, two transverse spots in the middle, and sometimes a few white hairs in front of the spinnerets. On the under

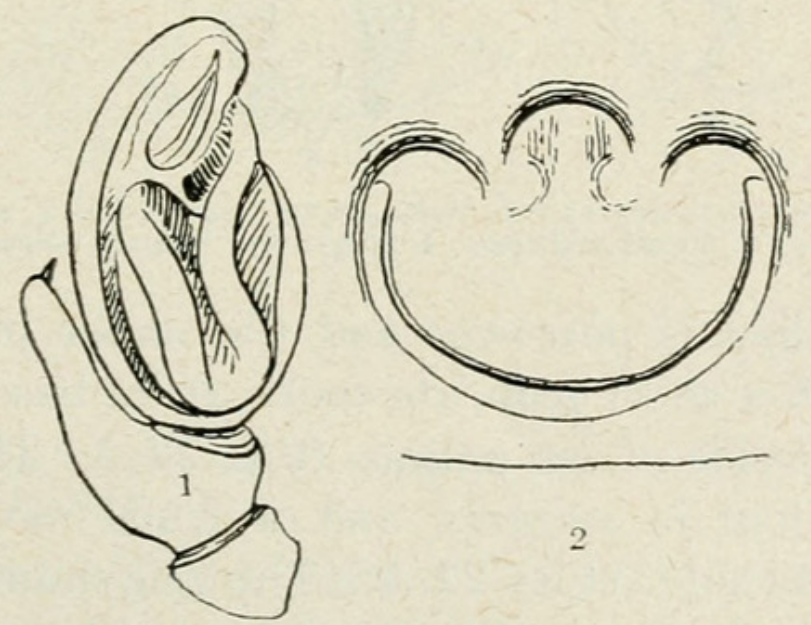

Fig. 21.-Pacilochroa columbiana. 1, male palpus, under side; 2, epigynum. 
side there are no definite markings, but the abdomen is usually lighter in the middle and toward the front, and the posterior coxæ are lighter than those in front. The male is darker than the females. The epigynum has a middle and two lateral pits in front, and a rounded lobe directed backward and fitting into a larger depression. (Fig. 21, 2.) The male palpus somewhat resembles that of $P$. montana, but the process of the tibia is smaller and the point less turned backward. (Fig. 21, 1.) This species is distinct from $P$. pacifica Bks., with which it has been compared.

Departure Bay, Vancouver Island, 1913, T. B. Kurata.

\section{Philodromus canadensis, n. sp.}

$5 \mathrm{~mm}$. long. Second femur of male $3 \mathrm{~mm}$. Marked in gray (Fig. 22,3) much like $P$. vulgaris and like $P$. bidentatus with which it is sometimes associated, but it does not have the sharp division between the dorsal and ventral colour areas that is usual in vulgaris. It has somewhat shorter legs than bidentatus, especially in the males. The male palpi resemble those of vulgaris, but the outer
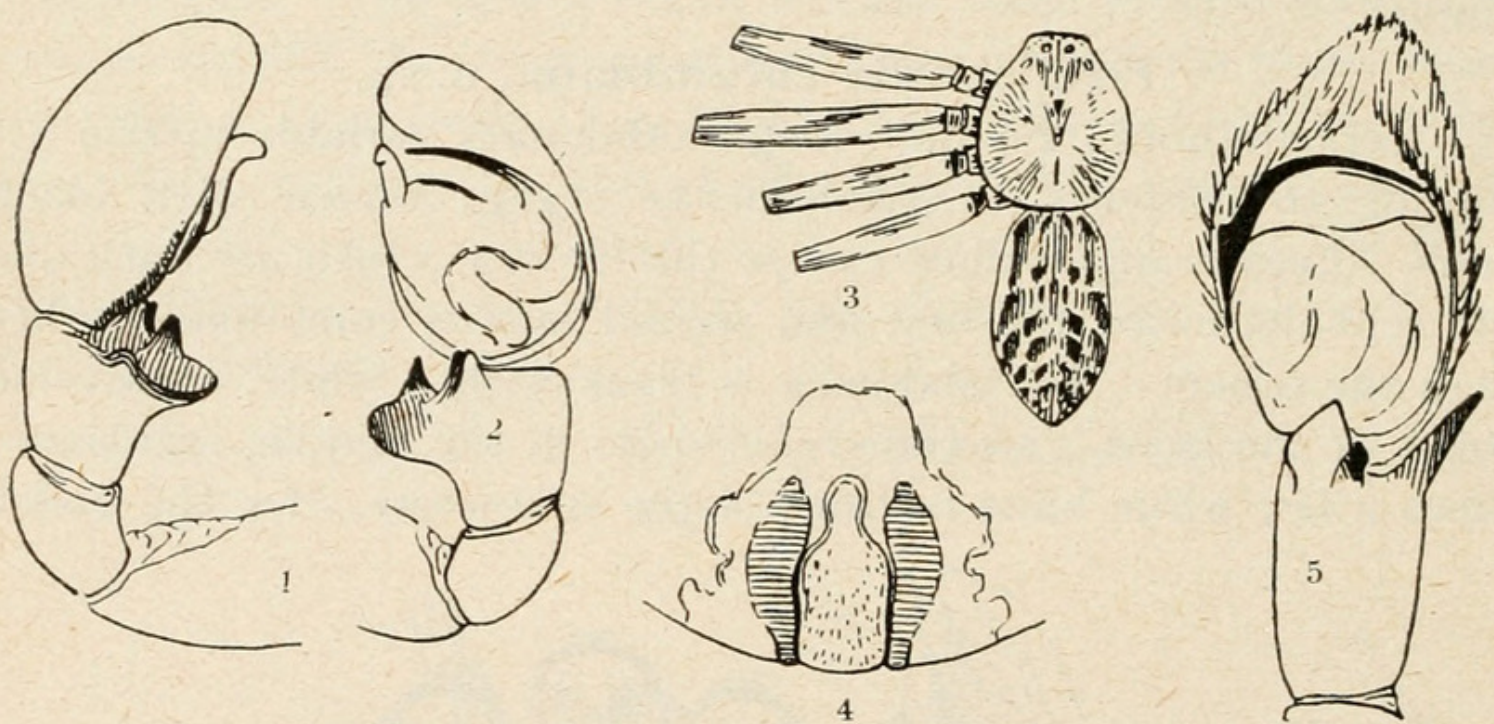

Fig, 22.-Philodromus macrolarsus. - 1, male. palpus, upper side; 2 , male palpus, under side. Philodromus canadensis. - 3, dorsal markings; 4 , epigynum; 5 , male palpus, under side.

process of the tibia is narrower and the under process more triangular and with a short truncate tooth at its base, a little curved toward the outer side of the palpus. (Fig. 22, 5.) The tibia is wider in the middle than in vulgaris, and widened more on the inner than on the outer side. (Fig. 22,5.) The epigynum resembles that of vulgaris, but is shorter. (Fig. 22,4.) 
Common about Montreal and Ottawa and westward to Lake Nipigon and Prince Albert; Grand Isle, Lake Champlain; Sandusky, Ohio.

\section{Philodromus macrotarsus, n. sp.}

$4 \mathrm{~mm}$. long. Femur of second leg $3 \mathrm{~mm}$. The specimen, a mále, is freshly molted and light in colour. The abdomen has a series of transverse marks in light and dark gray, and the legs are indistinctly ringed in the middle and near the ends of the joints. The male palpus has the tibia twice as wide as long, most of the width being on the outer side. (Fig. 22,1 .) On the projecting portion is a black pointed process directed forward and visible from above or below. On the under side is a double process also directed forward, the outer half dark and the inner half translucent brown. The palpal organ has on the end near the outer side a short, stout process curving downward and opposite to it is the dark pointed tube. (Fig. 22, 2.)

Vineland, Ontario. W. A. Ross, Sept., 1916.

\section{Chalcoscirtus carbonarius, n. sp.}

Female $4 \mathrm{~mm}$. Male $3 \mathrm{~mm}$. long. Dark gray, the male almost black, the female with the abdomen lighter than the cephalothorax and lighter below than above, without any markings. There are very small, scattered hairs all over the body and the skin is roughened with fine, irregular lines, and in some lights is
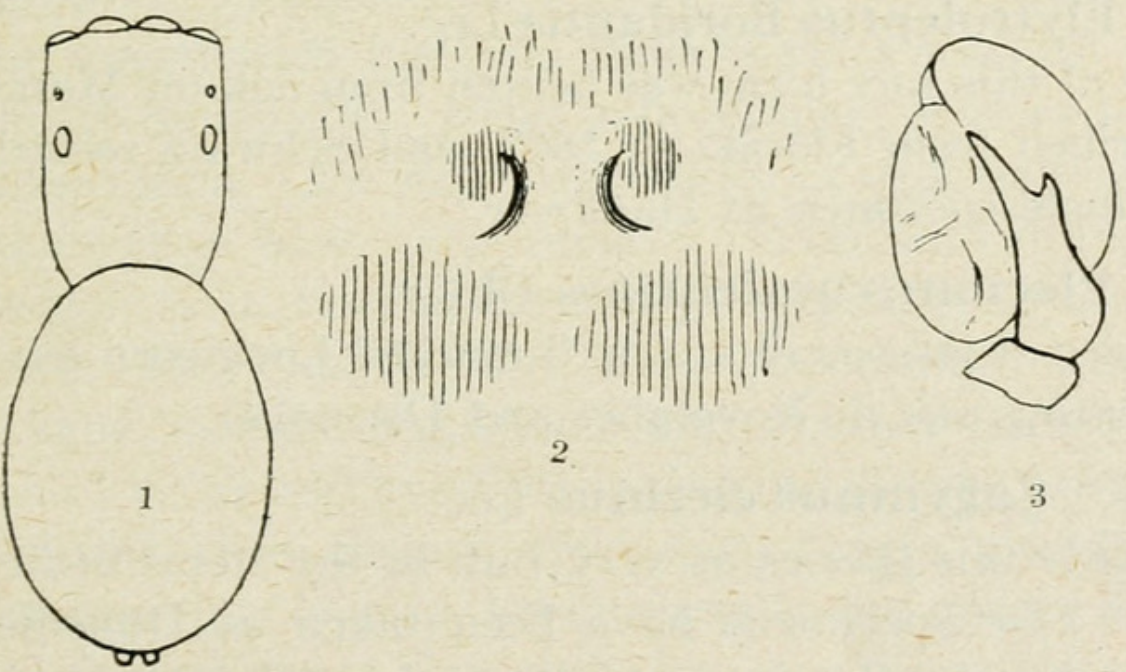

3

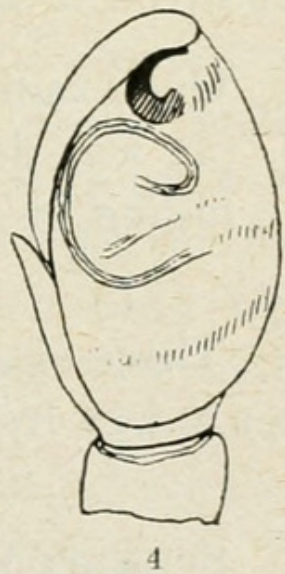

Fig. 23.-Chalcoscirtus carbonarius. - 1, outline of female; 2 , epigynum; 3 , male palpus' outer side; 4 male palpus, under side.

slightly iridescent. The abdomen is longer than the cephalothorax. The cephalothorax is one-half longer than wide, with the 
sides straight and parallel. (Fig. 1.) The eye area is wider than long, the front row of eyes covers the whole width of the head, and the small, middle eyes are nearer the upper pair than the front row. The leg of the first pair is not much thicker than the others in either sex, and the tibia has on the under side three pairs of long spines. The mandibles have no teeth under the claw. The male palpi have the tibia as long as wide, with a long process extending half the length of the tarsus and having a sharp tooth in the middle of the upper edge. (Fig. 23,3.) The palpal organ is oval and thick, extending back at the base over part of the tibia. (Fig. 23, 3 and 4.) The tube is at the tip and is short and curved in a half circle. (Fig. 23, 4.) The epigynum hastwo small, semi-circular openings behind which the round spermathecæ show through the skin. (Fig. 23, 2.)

Simpson summit, 7,000 ft., near Banff; a smaller species, $C$. montanus Banks, is found on Mt. Washington, N. H., above the trees.

\section{ON SOME NEW OR NOTEWORTHY COLEOPTERA FROM THE WEST COAST OF FLORIDA.-III.}

BY W. S. BLATCHLEY, INDIANAPOLIS, IND.

(Continued from page 240.)

\section{Elytroleptus floridanus Lec.}

One example of this rare form was beaten from oak on March 23. It was described from Florida in 1862, and Schwarz records the taking of a single specimen at Haulover.

\section{Plectomerus dentipes Olivier.}

Three examples of this small and well-marked Longicorn have been taken by beating oak in November and December.

\section{Zagymnus clerinus Lec.}

Schwarz records this species as very rare in the stems of dry palmetto leaves. Five specimens have been taken at Dunedin, three on pine lumber in October and December, the others at electric porch light in June. Two of the five are wholly black, one of them being $19 \mathrm{~mm}$. in length. The others are typical in hue, the head and thorax red and the elytra maculate, the length $13-15 \mathrm{~mm}$. 


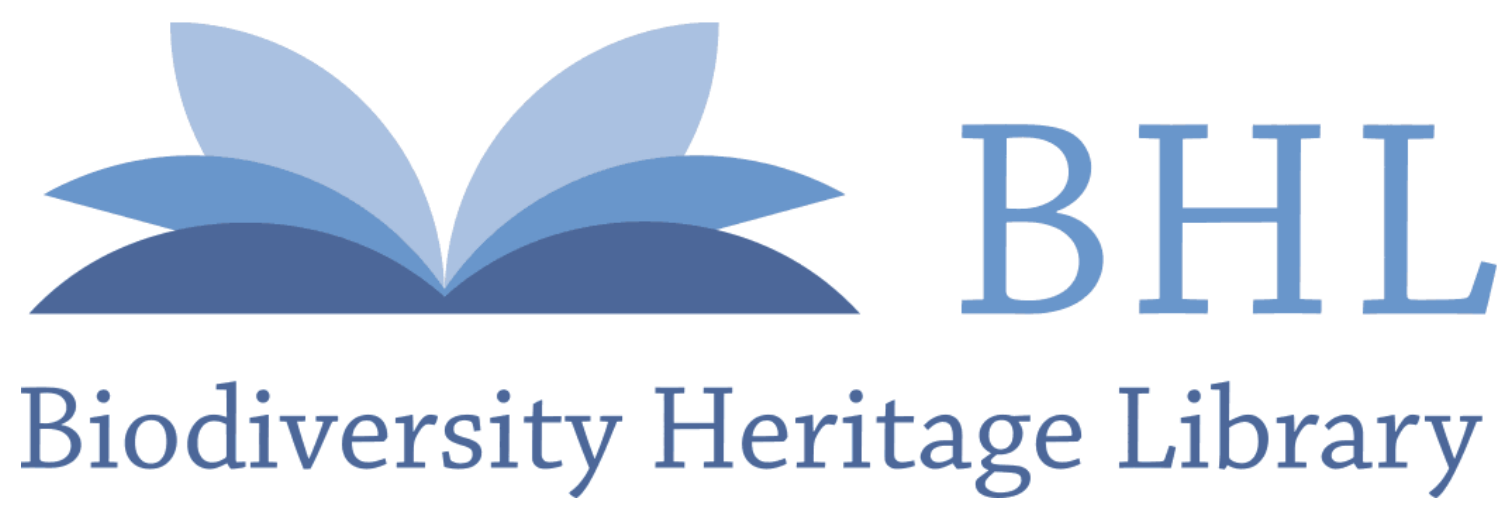

Emerton, J. H. 1917. "New spiders from Canada and the adjoining states." The Canadian entomologist 49, 261-272.

View This Item Online: https://www.biodiversitylibrary.org/item/22200

Permalink: https://www.biodiversitylibrary.org/partpdf/40133

\section{Holding Institution}

MBLWHOI Library

\section{Sponsored by}

MBLWHOI Library

\section{Copyright \& Reuse}

Copyright Status: NOT_IN_COPYRIGHT

This document was created from content at the Biodiversity Heritage Library, the world's largest open access digital library for biodiversity literature and archives. Visit BHL at https://www.biodiversitylibrary.org. 